\title{
TTR
}

Traduction, terminologie, re?daction

\section{Oedipus the King: A Greek Tragedy, Philosophy, Politics and Philology}

\section{Ekaterini Nikolarea}

Volume 7, numéro 1, 1er semestre 1994

Genres littéraires et traduction

URI : https://id.erudit.org/iderudit/037174ar

DOI : https://doi.org/10.7202/037174ar

Aller au sommaire du numéro

\section{Éditeur(s)}

Association canadienne de traductologie

ISSN

0835-8443 (imprimé)

1708-2188 (numérique)

Découvrir la revue

Citer cet article

Nikolarea, E. (1994). Oedipus the King: A Greek Tragedy, Philosophy, Politics and Philology. TTR, 7(1), 219-267. https://doi.org/10.7202/037174ar

\section{Résumé de l'article}

La tragédie grecque d'Oedipe roi: philosophie, politique et philologie - Cette étude tente de montrer que l'abondance des traductions, imitations et réinterprétations radicales d'un genre comme la tragédie tient à divers discours sociaux des sociétés cibles. En prenant l'exemple d'Oedipe roi de Sophocle, tragédie célèbre s'il en est, cet essai traite de la façon dont les discours philosophiques, politiques et philologiques ont influé sur la réception de la tragédie grecque classique par les systèmes cibles français et britanniques à la fin du XVIIe siècle et au début du XVIIIe, ainsi qu'à la fin du XIXe siècle et au début du XXe. La première partie montre comment, en faisant de la pièce de Sophocle un modèle grec de tragédie, la Poétique d'Aristote a donné forme à la critique littéraire et à la dramaturgie occidentales. La deuxième partie essaie de montrer pourquoi trois imitations d'Oedipe par Corneille (Oedipe), Dryden (Oedipus) et Voltaire (Oedipe) ont connu plus de succès que n'importe quelle « réelle » traduction contemporaine de la pièce de Sophocle. La dernière partie présente l'hypothèse selon laquelle la renaissance d'Oedipe roi à la fin du XIXe siècle et au début du XXe en France et en Angleterre est due à l'influence variable qu'exercent trois discours qui entrent en conflit mais aussi se chevauchent, ceux de la philosophie, de la philologie et de la politique. C'est une illustration de l'influence qu'exercent ces discours sur la réception de la pièce grecque dans les systèmes cibles français et britanniques.

Tous droits réservés ( $\mathrm{C}$ TTR: traduction, terminologie, rédaction — Les auteurs, Ce document est protégé par la loi sur le droit d’auteur. L’utilisation des 1994 services d’Érudit (y compris la reproduction) est assujettie à sa politique d'utilisation que vous pouvez consulter en ligne.

https://apropos.erudit.org/fr/usagers/politique-dutilisation/ 


\section{Oedipus the King: A Greek Tragedy, Philosophy, Politics and Philology}

\section{Ekaterini Nikolarea}

\section{Introduction}

How is it that Sophocles' Oedipus the King has been translated and re-interpreted over and over again? This essay will venture to answer this question by examining the relation of the very "canonical" genre of tragedy to discourses of philosophy, politics and philology. In the first section, we shall summarize Aristotle's Poetics and discuss how this treatise on tragedy, a philosophical discourse and a critical canon in itself, has offered a Greek model

1. I am especially grateful to The Killam Trusts in Canada and the Graduate Scholarship Committee of the University of Alberta who awarded me with a Pre-Doctoral Izaak Walton Killam Memorial Scholarship and a Province of Alberta Graduate Fellowship and, thus, enabled me to carry out the research required for this kind of study. My special thanks are also due to my friends the University Professor E.D. Blodgett (University of Alberta), Sheila Mawson and Don Wiley who read and made valuable comments on the manuscript; neither of them, however, is responsible for any errors of interpretation or of argumentation in this study. Finally, I would also thank Professor M.V. Dimić and Dr. Steven Tötösy de Zepetnek for allowing me to use the computer facilities of The Research Institute for Comparative Literature, University of Alberta. 
of tragedy of which Oedipus the King forms the socio-aesthetic landscape of the Western literary criticism and playwriting.

The second section will try to show how Aristotelian tradition evolved into Neoclassicism and which discourses were involved in that development. We shall also demonstrate how contemporary politics and politics of literary criticism and of theatrical performance were intertwined in the making of three "imitations" of Oedipus by Corneille, Dryden and Voltaire, and why these neoclassical versions became more popular than any other contemporary "real" translation of Sophocles' Oedipus the King.

In the third and largest part of this study, we shall propose that the revival of Greek tragedy in general and of Oedipus the King in particular in late 19th-and early 20th-century Europe was due to three conflicting but overlapping discourses: philosophy, philology and politics. Choosing only the French and British target systems (TSs) from the wider European polysystem, we shall compare the different degrees of influence of these discourses upon some French and British versions and translations of Oedipus the King and, eventually, discuss the difference in perception and reception of this tragedy by these systems.

\section{Aristotle's Poetics}

Aristotle's Poetics has been the foundation for practically all discussions of tragedy since the 16th century and has exerted incalculable influence on Western playwriting and critical theory. In this section, we shall start with a brief summary of this critical work and then discuss which aspects of The Poetics related to Sophocles' Oedipus the King either became the springboard for the neoclassical versions of Oedipus, or, having been radically re-interpreted by Friedrich Nietzsche, pushed translators, producers and creative writers in a different direction.

The extant Poetics now consists of 26 chapters that we shall divide into five sections: chapters 1-5, 6-22, 23-24, 25 and 26. 
In the first and introductory section (chs. 1-5), Aristotle deals briefly with the psychological and historical origins of poetry and gives a concise account of the development of tragedy; he also proposes to discuss epic, tragedy and comedy as the main kinds of poetry, defining them as forms of imitation (mimesis). ${ }^{2}$ In the second section (chs. 6-22), Aristotle gives his much-discussed definition of tragedy, and then proceeds to analyze and discuss the structure and the emotional effect of this genre. In the third section (chs. 23-24), Aristotle deals with epic poetry and the principles of its construction, what it has in common with tragedy, and wherein the two differ. The fourth section (chapter 25 ) is a long section on problems and solutions and is of particular importance, because it contains the fullest Aristotelian view of what is expected of a poet; it also includes his defence of poetry. In the last section of this treatise (ch. 26), Aristotle is concerned with the relative excellence of epic and tragedy. Comparing these two genres, he argues that, although Homer is the greatest poet, tragedy in the hands of Sophocles, as it is manifested in Oedipus the King, becomes superior to epic as artistic genre. Aristotle holds this position because he believes that Oedipus the King has the best plot and sets an example to follow.

One of the most important elements of The Poetics is the plot (mythos) which, according to Aristotle, is the heart of a tragedy, and everything revolves around it. At this point of our discussion, we need to understand how Aristotle uses this term in his Poetics. He takes over the word as used for a "legend," a "story" or a "myth," and in the course of the discussion, he sharpens and defines it to the point of becoming a technical term which is usually translated as "plot." A distinction between these two denotations of mythos in The Poetics is of crucial importance, because it shows, as we shall discuss later, first, the degree of influence of this critical work and Aristotle's discussion of Sophocles' Oedipus the King upon the neoclassical versions of Oedipus, and, second, how Nietzsche's re-interpretation of this

2. The different interpretations of the Aristotelian notion of mimêsis go beyond the scope of this study. 
term led to new versions of the Oedipus myth in the late 19th and early 20 th century.

Furthermore, in The Poetics, the word mythos, when interpreted as "plot," is inseparable from the character and action and closely related to such notions as probability, necessity and credibility. The plot is also connected to concepts such as hamartia, an error in judgement which derives from ignorance of some material fact or circumstance, reversal (peripeteia) ${ }^{3}$ and discovery or recognition (anagnōrisis).

\section{The Neoclassical Tradition}

It is not possible to jump directly from Aristotle's Poetics and his discussion of the plot and Sophocles' Oedipus the King to the neoclassical versions of this tragedy without considering the Renaissance and the unchallenged reputation Oedipus has enjoyed since then. Although the development of Greek tragedy into its Humanist counterpart goes beyond the scope of this paper, it is worth mentioning that during the Renaissance Oedipus was considered as the Greek tragedy par excellence. This reputation, however, originated less in the recognition of the play's excellence than in the prominence of the play in Aristotle's Poetics. His references to Oedipus the King, as an outstanding example of a well-structured play, encouraged the interpretation that he had derived the rules of a genre like tragedy primarily from this Sophoclean tragedy. Although in his Poetics Aristotle also refers to a number of other plays no longer extant, it was Renaissance writers who believed and bestowed on Oedipus the King the same canonical status as they had given to Poetics. It is also significant that the reputation Oedipus enjoyed as the tragedy

3. Peripeteia should not be interpreted simply as "reversal of fortune," as it is usually the case, but rather either as "reversal of intention," when it is seen from the character's perspective, or as a "reversal of the direction of action" when it is viewed from the angle of the spectator or reader. For the sake of simplicity, I render peripeteia into the all-inclusive term "reversal." 
par excellence during the Renaissance was a matter of prestige rather than a thematically oriented response to the subject of the play.

Interestingly enough, with the evolution of neoclassical dramaturgy and the fading of a subject-centered response to tragedy, the prestige of Oedipus increased even further. But the more this play was cherished as the paradigm of the Aristotelian rules, the more some neoclassical writers reacted against it. It was not surprising, then, that playwrights like Corneille and Voltaire in France and to a lesser degree Dryden in England, approached Oedipus with a critical eye on their own works and tried to improve on those aspects of this tragedy that, as they believed, did not quite follow the premises of Aristotle's Poetics. Although they agreed with Aristotle on the governing principles of the plot, Corneille, Dryden and Voltaire all disagreed with his stance that Sophocles' Oedipus the King has the best plot. They considered that there were too many flaws in Oedipus' character and improbabilities in his discovery (anagnoirisis) of the truth. Furthermore, they found the plot of Oedipus itself meagre and insufficient to furnish them with enough substance for their versions. Therefore, in order to attract their contemporary theatrical audience, Corneille, Dryden and Voltaire all introduced a sub-plot of secondary persons in their versions, with the consequences that some of these secondary characters became as important as Oedipus.

\subsection{Corneille's CEdipe}

After an interval which followed the unfavourable reception of his Pertharite in 1653, Corneille re-entered the Parisian theatrical lists with CEdipe in 1659. Fouquet had given Corneille three topics from which to choose and write a play; Corneille chose Oedipus and soon became aware of the difficulties he had to face in "imitating" Sophocles' tragedy. If his play were to earn him an immediate success, he had to follow the tastes of the day. Keen as usual, Corneille had already realized that the topic, perfect for 5 th-century Athens, had many aspects that would not be accepted by his 17 th century-French audience. For example, 
Oedipus' blinding would "soulever la délicatesse de [nos] dames" (Corneille, 1987, p. 18). ${ }^{4} \mathrm{He}$ thus decided not to bring his hero on stage after his mutilation. Likewise, Corneille introduced a subplot, the love of Dirce and Theseus, to distract his audience's mind from the atrocities of the legend. In doing so, nevertheless, Corneille removed Oedipus from his position of preeminence, and Oedipus' quest for knowledge and truth became nothing more than the starting point and background for the love intrigue that dominates this version. When his CEdipe was first produced in Paris in 1659, it immediately became one of his greatest successes.

Now, if we wonder how French politics during Corneille's lifetime is interwoven with his CEdipe, the answer comes from a close examination of both the general atmosphere and the delineation of the main characters of this play. The first main difference between Corneille and Sophocles' Oedipus is in their general atmosphere. Corneille's CEdipe has nothing of the terrifying anxiety and tension of Oedipus' inquiry; nor does the reality of the plague and death reach the court. The other main difference between Corneille and Sophocles' Oedipus is in their delineation of characters. Whereas in Sophocles the chorus of Theban elders is the direct link between the king and the citizens and always reminds Oedipus of his responsibility toward them, Corneille's characters are conscious of their royal power and privileges above all and prone to exercise these privileges whenever they can. For example, the Corneillian Oedipus behaves like an absolute monarch of 17 th-century France when he tells Dirce, "Je suis Roi, je puis tout" (II, 1; p. 39) and refuses to marry her to Theseus. Dirce, on the other hand, is not slow in clashing with him, since she considers herself the rightful inheritor of Laius. On the level of composition, this conflict between Oedipus and Dirce shows something more: how Corneille, by adding a sub-plot, has created a second character similar to the traditional hero, but one who is more appealing to

4. Pierre Corneille, 1987; hereafter any quotations from this play are taken from this edition, and the page numbers appear in the text. 
his contemporary theatrical audience. Honour, duty, and a glorious memory are the ideals that explain Dirce's readiness for sacrifice:

$C^{\prime}$ est ainsi qu'un trépas qui me comble d'honneur

Assure sa vengeance, et fait votre bonheur,

Et que tout l'avenir chérira la mémoire

$D^{\prime}$ un châtiment si juste où brille tant de gloire. (II, $3 ;$ p. 45)

Nevertheless, Oedipus becomes the principal configuration of dominant political ideology and prevailing moral values of 17 th-century France in this tragedy. Having usurped Dirce's throne, Oedipus does not allow her to marry Theseus, giving no reasons immediately for his refusal; when he does, however, they are all specious. When Dirce points out the flaws in his arguments, he acts tyrannically saying, "Je pense être ici Roi" (II, 1; p. 37). At a time when the relation of politics and royal marriages was of primary importance, Oedipus plans to have Dirce married to Haemon, Creon's son, instead. He wants to do this because, as Dirce succinctly observes, in order to strengthen his position on the throne he cannot have her married to a man strong enough to contest his claim and position (II, 2; pp. 40-42). Thus Oedipus becomes both a usurper and tyrant. He may be king by the will of people as well as by marriage, but popularity has nothing to do with legitimacy in government. ${ }^{5}$ In this light, Oedipus can only be viewed as a degenerate hero, guilty of the basest Machiavellian manipulation of innocent people, like Dirce and Theseus. As such, his importance at the beginning of Corneille's CEdipe is secondary and even peripheral.

Despite his reaction to Dirce's request to marry Theseus, Oedipus himself remains throughout the play the mighty king, cold and haughty, who is not allowed to show any private feelings. When he is revealed to be the murderer of Laius, instead of crying with despair as the Sophoclean Oedipus does, he behaves as an idealized French king would have done: he learns the worst with a lofty serenity. Moreover, he insists on

5. A position that Corneille had already held in his Pertharite. 
exercising his divine authority which does not allow his people to judge him:

Mais ce n'est pas au Peuple à se faire justice. L'ordre que tient le Ciel à lui choisir des Rois Ne lui permet jamais d'examiner son choix, Et le devoir, aveugle y doit toujours souscrire, Jusqu'à ce que d'en haut on veuille s'en dédire. (V, 1; p. 79)

His first thought is to administer a stately rebuke to Phorbas and Iphicrates, those who had saved him from perishing in infancy; "Voyez où m'a plongé votre fausse prudence" (V, 3; p. 84).

Another significant aspect of the Corneillian delineation of Oedipus is in the final recognition (anagnorisis). Though the play ends divided between the love story (amour) of Theseus and Dirce fully realized, and the tragic end of Oedipus, Dirce and Theseus disappear before the grandeur of Oedipus at the end of the play $(V, 5 ;$ p. $86-V, 9 ;$ p. 93). During these moments Oedipus becomes the epitomy of the dominant political ideology and prevailing moral values of 17 th-century France. He reacts to his destiny as an "ideal" 17 th-century French king remaining calm and seeing himself as an innocent victim of fate, regaining his vertu through innocence $(V, 7 ;$ p. 89). Even when he blinds himself, Oedipus ensures the triumph of his royal essence by challenging the unjust gods to prove the validity of their judgement.

How successful Corneille's CEdipe was is evident from the records of La Comédie Française. It seems that it was performed ninety-four times between 1681 and 1729 and then, eclipsed by Voltaire's CEdipe, was never staged again (Joannidès, 1901, pp. xii-xiii).

\subsection{The Oedipus of Dryden and Lee}

Some twenty years after Corneille, John Dryden, in collaboration with Nathanicl Lee, wrote Oedipus to be produced for the season 
of 1678-1679. As he admitted, "I writ the first and third acts of Oedipus and drew the Scenary of the whole play" (Dryden, 1984, p. 443). ${ }^{6}$ This play was the result of Dryden's response to the problems that he had with his theatrical company, his publisher and his critical adversary Thomas Rymer (Dryden, 1984, pp. 441-444).

When we place Dryden and Lee's Oedipus beside their acknowledged sources in the plays of Sophocles, Seneca ${ }^{7}$ and Corneille, we are likely to be struck, first, by the sub-plot of Adrastus, Eurydice and Creon, in which love and politics play a very crucial role, and, second, by the catastrophe in which all the characters die. Following Corneille's CEdipe, Dryden sketches a sub-plot that could vary and complicate the main plot and introduces Eurydice who, being like Corneille's Dirce, is Laius' daughter. He also replaces Corneille's Theseus with Adrastus, the king of Argos, a character who is less likely to be "a greater Heroe than Oedipus himself" (Dryden, 1984, p. 116). Dryden did that because he believed that the development of the character of Theseus was one of the weakest aspects of Corneille's sub-plot, since he appears to be a greater hero than Oedipus, and eventually diverts the attention of his audience from Oedipus himself.

One of the most interesting characters in Dryden's Oedipus is Creon, who was mentioned by Corneille in passing but not allowed to appear on stage. Dryden's Creon is not, however, the noble and blameless Creon of Sophocles' Oedipus the King but rather a villain. In Dryden's Oedipus, Creon is charged with uniting the tragedy structurally and thematically. From a structural point of view, it is the character of Creon who unites

6. Any emphasis appeared in the text is Dryden's unless otherwise indicated.

7. The other classical model upon which all the neoclassical versions of Oedipus were drawn was Seneca's Oedipus. This Latin writer was perhaps one of the most influential writers upon Shakespearean, Jacobean and Neoclassical writers. 
the main plot and sub-plot of the Jacobean poet, a task discharged in Corneille by Dirce with some assistance from Theseus. Moreover, and from a thematic point of view, Creon is busy in two plots, aspiring, first to rule in place of Oedipus and, second, to detach Eurydice from her loved Adrastus so that he may marry or enjoy her himself. Perhaps more than any other character in this tragedy, Creon becomes a point of reference of literary antecedents and serves to bring on stage the fears and jealousies of contemporary English politics. On the one hand, delineated as a hunch-backed villain who courts Eurydice, Creon is rejected by her much as Shakespeare's Richard, Duke of Gloucester, is repulsed by Lady Anne. ${ }^{8}$ On the other hand, some traits of Creon's character could easily be applied to the political figure of Shaftesbury, as seen through royalist eyes. In this context, we shall refer only to one example which, nevertheless, can display a striking parallelism between Creon's behaviour and Shaftesbury's politics as described by the latter's political opponents. Just as Creon seized the opportunity of plague and foreign war to "insinuate" himself "into the multitude" and inflame the people against the court (I, 1; pp. 122-127), so Lord Shaftesbury was considered by loyalists to be using his influence for his advantage when he himself pressed other politicians for war with France. ${ }^{9}$ Even Creon's physique becomes a trope of Shakespearean dramaturgy and politics of 17th-century England. His physical deformity not only coincides with that of Richard in Shakespeare's Richard III but also with the condition of Shaftesbury who, by the summer of 1678 , was bent and walked with the help of a stick. To a villain such as Creon, Dryden counterposes a king of excellent public character, much like Sophocles' Oedipus, as Dryden himself thought, and unlike Corneille's Oedipus who was "suspicious, designing, more anxious

8. Shakespeare's Richard III.

9. During the years 1677-1678 England came close to being drawn into the war between France and Holland. There are overt references to that war in Dryden's «Prologue» and «Preface» to Oedipus. 
of keeping the Theban Crown, than solicitous for the safety of his People" (Dryden, 1984, p. 115).

At this point, a brief summary of Dryden and Lee's Oedipus is necessary in order to understand how Sophocles' Oedipus the King was transformed into a Jacobean tragedy by these two playwrights. When the play opens, Oedipus is absent from Thebes engaged in war with Argos; meanwhile Creon is laying plots against his throne. When Oedipus returns, he brings the captive Adrastus, whom he chivalrously sets free to woo Eurydice. From this point on, the play follows the general lines of Sophocles, so far as the discovery (anagnōrisis) is concerned. The main difference between Sophocles and Dryden's Oedipus is that in the latter Oedipus is denounced not by Teiresias but, as in Seneca, by the ghost - which Dryden, unlike Seneca, brings on the stage. Morcover, the tragic climax is reached with the death of Eurydice, who is stabbed by Creon. After Creon has stabbed Eurydice, a massacre occurs. Creon and Adrastus kill each other; then Jocasta slays herself and her children and, finally, Oedipus throws himself from the palace walls. Although Dryden had never intended to divide our sympathy between the fate of Eurydice and Oedipus, his Oedipus does exactly that. It also involves feelings such as loathing for the villainy of Creon, and disgust at the wholesale butchery of the end. To understand, however, all the drastic modifications in this English version of Oedipus, we need to contextualize this play, first, in Dryden's literary criticism and theory of translation and, second, in its own culture.

As noted earlier, Oedipus was Dryden's response to his long critical debate with Rymer about "Ancients and Moderns," and the former's efforts to shorten the aesthetic distance that the latter had set between the Jacobean and Athenian dramatists. By making an English version of antiquity's masterpiece, like Oedipus the King, Dryden tried to prove to Rymer that there was a continuing dramatic tradition from Ancients to Moderns, and introduced a sub-plot to improve upon the "ancient method." In the "Preface" to Oedipus, Dryden claims that the sub-plot justifies its presence on the basis of "Custom" alone (Dryden, 1984, p. 116). 
This phrasing in itself is very intriguing because it has converged with what has become very clear from the rest of Dryden's published and unpublished remarks: that he was not concerned with producing something conformable to "the spirit of Greek tragedy" but rather something closer to the "English Genius." Had he written Oedipus according to "the spirit of Greek tragedy," such a play would have been a paraphrase. ${ }^{10}$ Although Dryden's Oedipus has paraphrastic moments in several scenes, it is rather an imitation, or the "Endeavour of a later Poet to write like one who has written before him on the same Subject: that is, not to Translate his words, or to be Confin'd to his Sense, but only to set him as a Pattern, and to write, as he supposes, that Authour would have done, had he liv'd in our Age, and in our Country" (Dryden, 1956, p. 116). After all, "'Tis not enough that Aristotle had said so, for Aristotle drew his Models of Tragedy from Sophocles and Euripides; and if he has seen ours, might have chang'd his Mind" (Dryden 1971, lines 13-15, p. 191). To put it another way, Dryden and Lee's Oedipus as a whole strives to capture not "the spirit of Greek tragedy," but the spirit of the age and country in and for which it was written - Restoration England.

This Jacobean version of Oedipus was popular for almost a century for it was performed and published several times (Dryden 1984, pp. 446-447). Its last recorded performance occurred in January 1755 but "the audience were unable to support it to an end; the boxes being all emptied before the third act was concluded. Among all our English plays, there is none more determinedly bloody than "EEdipus," in its progress and conclusion" (Dryden, 1812, p. 121). How much the taste of British

10. Paraphrase was one of the terms Dryden later used to distinguish between three kinds of translation: (1) metaphrase, when the translator turns an author word by word, and line by line, from one language into another; (2) paraphrase, or translation with latitude, which is the Ciceronian «sense-for-sense» view of translation; and (3) imitation occuring when the translator shapes the original text as he sees fitting in his own historical needs and context (Dryden, 1956, p. 109-119). 
public changed can also be seen in the brief note preceding the text in the 1791 edition of the Oedipus when it was published in the series Bell's British Theatre. That note assured the reader that Oedipus "seldom makes its appearance upon the modern stage, and is hasting, with all its mythological brethren, to that repose, which only solitary curiosity disturbs in the silent though classic ground to the library" (Dryden, 1984, p. 447).

\subsection{The CEdipe by Voltaire}

When Voltaire wrote $C E$ dipe, his own tragedy and his first work at the age of nineteen, he had been well-acquainted with Sophocle's Oedipus the King, Seneca's Oedipus, and Corneille's CEdipe. He had studied Aristotle's Poetics, and known the tragic theories of his time, in particular those by Dacier. Nonetheless, he decided to write his own Oedipus because he was not satisfied with the other models. In his "Third Letter on CEdipe," Voltaire admitted that this Greek tragedy did not satisfy 18th-century French standards because it provided material for one or two scenes only, never for a whole tragedy (Voltaire, 1967, pp. 18-28). It becomes evident from this letter that indeed Voltaire approached the Sophoclean model to point out, and, eventually, to rectify its considerable number of contradictions and vain declamations (Voltaire, 1967, pp. 26-28).

Nevertheless, and in spite of his criticism of Corneille's CEdipe, ${ }^{11}$ Voltaire has in many respects followed him. He introduces a love plot, this time between Jocasta and Philoctetes, because, as he claims, the Parisian actors had threatened him that they would not perform an CEdipe without love in it! ${ }^{12}$ Then in the first three acts of the play Oedipus can hardly be said to be at the centre of the action. These acts turn almost entirely around Jocasta and her lover, Philoctetes, who after the death of his friend Hercules has come back to Thebes to see her. For Voltaire,

11. «The Fourth Letter», Voltaire, 1967, pp. 28-35.

12. Voltaire's letter to the Jesuit father Charles Porée on 7 January 1731 (Voltaire, 1963, pp. 235-237). 
who found the opening scene of Sophocles too contrived, Philoctetes' arrival offers a plausible reason for the introductory scenes. Revisiting Thebes, after a long absence, Philoctetes finds Oedipus reigning in the seat of the deceased king. Known as an old foe of Laius, Philoctetes is now accused of having murdered him by the Thebans, who are vexed by the plague and eager to find a victim for the angry god. Jocasta, who had been betrothed to him in youth, and still loves him, urges him to flee. He, however, resolves to remain and confront the false charge. At this moment the High Priest denounces Oedipus as the criminal. Philoctetes generously protests his belief in the king's innocence, and from this point on until the end of the third act, he appears no more.

Having accused Sophocles of revealing the outcome of the tragedy right from the beginning in Teiresias' prophesy to Oedipus, Voltaire re-arranges the plot of his own version so that the dramatic tension is maintained until the end. For this reason, Voltaire argues that the discovery in his own version takes place in two stages, as it does in Corneille's CEdipe. Sophocles, Voltaire says, has forgotten that Laius' murder is the first theme of the inquiry, and that the murderer's presence in Thebes is the reason for the plague. After the opening scenes, Sophocles, Voltaire claims, never mentions the plague again, nor is Oedipus explicitly proved to be the murderer of Laius and thus responsible for the suffering of his people; instead Sophocles' emphasis is on Oedipus' self-knowledge (Voltaire, 1967, pp. 18-28). Therefore, and in contrast with Sophocles, Voltaire shows his hero beginning his criminal investigation immediately upon receiving the High Priest's report. When he learns from Jocasta that Phorbas, the equivalent of the shepherd, is still alive, Oedipus asks that he be summoned. Later on, when he understands that he has killed the former king, he is ready to sacrifice himself for his people. He is on the point of leaving for exile when the Corinthian messenger arrives, and the second stage of discovery (anagnörisis) occurs. The play ends with Jocasta stabbing herself after Oedipus' blinding has been announced. 
By writing a new Oedipus, the young Voltaire not only tried to improve on his predecessors but also found the opportunity to express some of his political ideas. There is no doubt that some statements like Philoctetes':

Un roi pour ses sujets est un dieu qu'on révère;

Pour Hercule et pour moi, c'est un homme ordinaire (II, $4 ; \mathrm{p}$. 78),

were highly controversial in a play performed at the time of the Regency. Yet, it is upon the character of Oedipus that Voltaire's political discourse is concentrated. Unlike his Corneillian counterpart, Voltaire's Oedipus is not an absolute king. He is the "ideal" of an enlightened king ("un monarque éclairé"), ${ }^{13}$ who acts like a chief magistrate rationally and conscientiously in the examination of evidence. He proceeds rationally and speedily. The mere inability to procure Phorbas on the spot delays the recognition (anagnörisis). Voltaire does not make use of the ambiguity concerning the number of murderers, and Phorbas, who enters immediately following the scene between Oedipus and Jocasta, can only confirm that Oedipus is indeed the murderer of Laius. The act concludes with Oedipus resolution to leave Thebes for ever.

By making Oedipus formally conclude his investigation of the murder of Laius, Voltaire may have achieved "vraisemblance" in the portrayal of an enlightened king but has lost the effect of the Sophoclean irony. His drama is no longer that of truth and self-knowledge but merely an example of good judicial procedure. Consequently, Voltaire's fifth act with its revelation of Oedipus' identity appears rather as a mere appendix to a successfully concluded investigation and is distinctly anticlimactic.

13. Considering that Voltaire is one of the most important representatives of Enlightment, the delineation of his Oedipus carries out traces both of his personal beliefs and the change of attitudes in pre-revolutionary France. 
Voltaire's CEdipe was a great success in its time, first, because of its obvious relation to ancient tragedy and classical French models in subject and style and, second, because of its closeness to the spirit of Voltaire's time and the rise of free thinking (libertinage). At the end of the 18th century new Oedipus plays were written, ${ }^{14}$ but it was Voltaire's CEdipe that was staged by La Comédic Française for three hundred and thirty-six times until 1852 (Joannidès, 1901, pp. xviii-xix).

\section{The Late 19th- and Early 20th-Century Revival of Greek Tragedy: France and England}

After the demand for translations and performances of Greek tragedies and Oedipus the King had declined for at least a century, a new interest in Greek literature and tragedy was noticed in the late 19 th and early 20 th century. How did that revival of Greek tragedy and Oedipus happen? A simple explanation, accounting for all its widely different aspects, is not possible. Nor is it possible to determine the influence of one single work or writer, or one specific reason, that could be seen as a starting point for the new approach to Greek tragedy. A great number of factors are involved, not all of them purely literary or dramatic, but part of the development and overlapping of different discourses of philology, philosophy and politics. On the one hand, posivitism with its stress on objective and scientific methods was, among many other things, responsible for a tremendous amount of thorough scholarship in historical, archaeological and philological studies that increased the knowledge of the ancient world in a degree never achieved before. On the other hand, the new theories on the meaning of the myths ${ }^{15}$ and their relation to history became an important source for symbolism in literature; the tendency to integrate imaginary beings for symbolic purposes

14. The most remarkable is CEdipe chez Admète by Jean François Ducis (1778) who combines the Oedipus at Colonus with the myth of Alcestis.

15. Bachofen and Frazer were two of the most prominent figures in the study of mythology in the 19th century. 
was also taken over in drama and became characteristic of the French and German re-interpretations of the Sphinx in the Oedipus myth. But these theories on mythology were closely related to philosophy, a discourse that played a crucial role in the revival of Greek tragedy during that period, and to the philosopher Friedrich Nietzsche (1844-1900), whose works and philosophical concepts had a great impact on many writers in and outside Germany in the two decades before and after 1900.

As a result of this revived interest, three distinct attitudes toward Oedipus the King can be discerned in the wider European context during that period. First, some classical philologists, mainly in England and Germany, translated Oedipus aiming primarily at a scientific reconstruction of the past. Second, some others, fascinated by contemporary theories on mythology and tragedy, translated Oedipus in verse to make this tragedy more accessible to an average non-Greek public. Third, there was a more subjective attitude that can also be perceived as a truly original approach to the myth and the character of Oedipus. That tendency appeared primarily in France and Germany and was expressed in the form of versions whose action went beyond that of the Sophoclean Oedipus. Among the earliest examples are Péladan's CEdipe et le Sphinx (1897 and 1903) and Hugo von Hofmannsthal's Ödipus und die Sphinx (1906).

In the following sub-sections, we shall examine only the French and the British TSs and try to show how and to what degree discourses of philology, philosophy, and, when necessary, politics played an important role in the making of some French and English translations and performances and fostered the first French radical re-interpretation of Sophocles' Oedipus the King in the late 19 th and early 20 th century.

\subsection{France}

Up to the late 19th century, it was either Voltaire's neoclassical version of CEdipe or radical re-interpretations of Oedipus the King which dominated the Parisian stage rather than any "real" translations of this Sophoclean tragedy. The only exception to 
that rule was LaCroix's verse translation CEdipe Roi which was performed by Mounet-Sully with great success from 1880 to 1915.

Parallel to these tendencies towards Oedipus in Paris, there was a movement towards a revival of Greek tragedy in southern France, which was initiated by creative writers, poets and classical scholars. In the Greek theatre of Orange many productions of Greek plays were organized in an effort to revive the interest of the provincial French public in ancient Greek drama. Yet, the texts used in these performances were free adaptations rather than translations of various Greek tragedies. In the case of Oedipus the King, Péladan's radical re-interpretation of the Oedipus myth, CEdipe et le Sphinx, was produced in Orange in 1903. Although both Péladan and his CEdipe et le Sphinx are forgotten now, his version set the first example to be followed by other French playwrights who wished to write their own version of Oedipus, and dominated the French reception of Oedipus in the early 20 th century.

In the following exposition, we shall discuss, first, how the fortunes of LaCroix's translation depended upon Mounet-Sully's performances, which were of importance in the French and the British TSs, and, second, what kind of affinities there are between Péladan's OEdipe et le Sphinx and Nietzsche's theories on Greek tragedy and Oedipus the King.

\subsubsection{LaCroix's CEdipe Roi and its performance by Mounet-Sully}

As noted carlier, it was Voltaire's CEdipe which, after its first successful theatrical production in 1711, dominated the French readership and continued to be staged by La Comédie Française until the middle of the 19th century (1851). Nevertheless, in 1858 CEdipe Roi, a verse translation fairly close to the Greek original 
made by Jules LaCroix, ${ }^{16}$ appeared on the French market and were to dominate the French readership and theatrical audience for almost half a century. It was for the first and the last time that a "real" translation of Sophocles' Oedipus the King made such a sensation in both France and abroad. The reason for that popularity was not, however, the merits of the translation itself; it was rather that it was staged by La Comédie Française, and the role of Oedipus was performed by Mounct-Sully, one of the best actors in late 19 th- and early 20 th-century France. It seems evident from the fact that when LaCroix's translation was first staged by La Comédie Française in 1858 it passed unnoticed. It was only in 1881, when Mounet-Sully played the role of Oedipus, that LaCroix's translation became universally accepted. It was Mounet-Sully's acting the part of Oedipus that was praised unreservedly by French, British and German theatrical critics and classical scholars. Sir R.C. Jebb, the leading philologist in England $^{17}$ wrote the following dithyrambic critique on Mounet-Sully's performance of Oedipus:

Probably no actor of modern times has excelled $M$. Mounet-Sully in the union of all the qualities required for a living impersonation of the Sophoclean Oedipus in the entire series of moods and range of passions which the part comprises; as the great king, at once mighty and tender $[. .$. tortured by slowly increasing fears, alternating with moments of reassurance; stung to frenzy by the proof of his unspeakable wretchedness; subdued to a calmer despair [...] The scene between Oedipus and Jocasta (vv. 700-862) should be especially noticed as one in which the genius of Sophocles received the fullest justice from that of M. Mounet-Sully. [...] with a modern audience, the moment at which the self-blinded Oedipus comes forth is that which tests the power of the ancient tragedy. $[\ldots]$

16. Jules LaCroix, CEdipe Roi, tragédie de Sophocle traduit littéralement en vers français par Jules LaCroix (1858); for consequent publications of this translation, see under "LaCroix" in the References of this study.

17. For the importance of this classical scholar for the English TS, see section 3.2.1. 
On the Paris stage, the traditions of the French classical drama (represented on this point by Corneille and Voltaire) were apt to make the test particularly sever. (Sir R.C. Jebb, 1893, pp. xlix-l)

Jebb's last statement is intriguing because it explicitly states that in contrast to the neoclassical tradition of Corneille and Voltaire, who avoided bringing the blinded Oedipus on stage, the self-inflicted hero appeared on the French stage for the first time, thanks to the excellent performance of Mounet-Sully and LaCroix's literal verse translation. Still, it is surprising that even Jebb, a classical scholar, praised Mounet-Sully's performance to a greater degree than LaCroix's translation. The same attitude towards Mounet-Sully and LaCroix is encountered in Saturday Review on November 19, 1881 (Sir R.C. Jebb, 1893, p. 1); whereas the former's performance was glorified, the latter's translation was not even mentioned.

These British appraisals are of great significance because they indicate that both the average British public and well-known scholars alike seemed more interested in the performance of Oedipus by Mounet-Sully than the translation used in that performance. One possible explanation for that predisposition might be that, although the British market was flooded with prose or verse translations of Oedipus the King, the play itself was banned from the British stage long before the end of the 19th century. ${ }^{18}$ It would not be an overstatement to claim that Mounet-Sully's performance of Oedipus might have been the springboard for the co-ordinated effort of English classical scholars, performers and critics to overturn the censorshsip of Oedipus in Great Britain. In like manner, not having said much about the translation, German scholars and critics were impressed by Mounet-Sully's performance; they applauded the seriousness of his performance as opposed to the vulgarity of vaudeville and the dreary Naturalist drama of the time (Kindermann, 1970, pp. 128-129).

18. For the banishment of Oedipus from the British stage, see Frank Fowel and Frank Palmer, 1969. See also sections 3.2.1. and 3.2.2. 
After his first performance of CEdipe (1881) and until his death (1915), Mounet-Sully continued to play successfully the role of Oedipus and, eventually, LaCroix's CEdipe Roi became Mounet-Sully's CEdipe. His famous performances in the role of Oedipus proved to be a great success of the classical repertoire at La Comédie Française for almost thirty-five years. After Mounet-Sully's death, however, it was thought impossible to continue the performances of CEdipe Roi at this Parisian theatre. Hence, a new and quite different version was sought and found in Saint-Georges de Bouhélier's CEdipe, Roi des Thèbes in 1919. In this way, Josephin Péladan is justified when he claims that the Parisian theatre public, "à peu près indifférent à l'œuvre $[. ..] n^{\prime}$ applaudit que l'interpretation. On ne va pas à CEdipe Roi, mais à Mounet-Sully" (Péladan, 1905, p. 73). Interestingly enough, Mounet-Sully's successful performances helped the fortunes of LaCroix's translation in the French TS itself. It seems that this translation became so popular, after it was first performed by Mounet-Sully in 1881, that it was published twice as often as it had been published before. More specifically, while LaCroix's translation was printed only four times from the time of its first publication (1858) to 1874, it was printed at least eight times from the time of its first performance by Mounet-Sully (1881) until $1901 .^{19}$

\subsubsection{Josephin Péladan's CEdipe et le Sphinx, and Nietzsche's The Birth of Tragedy (Die Geburt der Tragödie)}

(a) Josephin Péladan and CEdipe et le Sphinx

Josephin Péladan was one of the most prominent figures in the revival of Greek tragedy in southern France, and certainly the most original one. His CEdipe et le Sphinx (1897 and 1903) ${ }^{20}$ was performed in Orange on August 1st, 1903. The most obvious

19. For the consequent publications of this translation under "LaCroix» in the References of this paper.

20. Subsequent quotations are taken from the 1903 edition, and the page numbers appear in the text. 
difference between his CEdipe, Sophocles's Oedipus and the neoclassical versions of Corneille and Voltaire is in Péladan's choice of presenting an earlier moment in Oedipus' life in his play. Péladan's tragedy is divided into three acts and can be summarized as follows: the first act deals with the murder of Laius and the departure of Oedipus for Thebes; the second shows the funeral of Laius taking place and, soon afterwards, Oedipus arriving in Thebes; and the third act is about Oedipus victory over the Sphinx and his return to Thebes that leads to his wedding with Jocaste and his proclamation as the King of Thebes. Though all these elements are part of the myth, they were not taken up in Sophocles' Oedipus the King.

Perhaps the most fascinating and innovative part in Péladan's OEdipe et le Sphinx is the very existence of a hybrid being like the Sphinx. Considering that the Sphinx and its symbolism have become an essential part of the 20th-century French and German adaptations of Oedipus, ${ }^{21}$ Péladan's Sphinx acquires great importance, for in this play we encounter the first treatment of the Sphinx in this century. Described as "Cette panthère au visage, aux mamelles de femme / et dont l'intelligence confond celle de l'homme" (II, 5; p. 29), the Sphinx lives in a high rocky cave with bones of victims scattered all around. All the stress of the third act is primarily on the discussion between Oedipus and the Sphinx, which is dominated by the articulation of four enigmas. The first one is the traditional riddle to which the answer is "man," and which Oedipus has no problem in solving it (III, 2; p. 54). The second one is the Sphinx itself and the secret is to resist her horror:

\section{LE SPHINX}

Je suis moi-même l'énigme que je propose?

GEDIPE

21. By «adaptations» I do not mean adaptations of translations for stage performance which, nevertheless, follow the story-line of Sophocle's Oedipus the King. I refer instead to re-interpretations of Oedipus whose plot is radically different from that in Sophocles. 
Il s' agit, en effet, de résister à ton horreur

et, si j'avais tremblé, déjà je serais mort. (III, 2; p. 55)

Her nature had already been described by Teiresias in the second act: the corruption of the heart at the Theban citizens, as well as their curse on the plague-stricken Chalcidians, are responsible for the monster (II, 5 ; p. 30). Oedipus, too, sees her as an Erinys, but not being a Theban himself, he attributes to himself the godlike power to expiate the Theban sin (III, 2; p. 56). Then the Sphinx tries to seduce him, "La véritable énigme, crois-le, c'est mon baiser" (III, 2; p. 58). Oedipus resists and boastfully claims that he himself is the enigma, "C'est moi qui suis l'énigme, maintenant!" (III, 2; p. 59). And this is the very oracle he does not understand, in spite of the Sphinx explaining it to him in terms as clear as those of the Sophoclean Teiresias:

Mon vainqueur sera le plus malheureux des mortels.

Les mains rougies dans le sang de son père,

il ira se coucher dans le lit de sa mère,

ct il engendrera dans la chair où il fut engendré (III, 2; p. 59)

Far too intoxicated by his heroic mission, Oedipus does not listen to the statement of the Sphinx and kills her. The play ends with Oedipus and Jocasta sitting on the Sphinx's rock which has now become their royal throne.

Compared to the strict simplicity of Sophocles' Oedipus the King, the complexity of Péladan's version and the introduction of such a fantastic, chimeric being as the Sphinx are incompatible with Aristotie's premise that there should not be any marvelous or irrational incidents in tragedy:

Impossible probabilities should be preferred to possible improbabilites. The story should neither be made up of irrational incidents nor have anything irrational at all in it; if this is, however, impossible, the irrational should lie outside the plot, as in Oedipus' ignorance of how Laius died; it should not be in the play itself [...] (Ch. 24 of The Poetics or The Poetics 1460a, 26-31; translation mine) 
Furthermore, compared to the neoclassical versions of Oedipus in which Corneille, Dryden and Voltaire tried to improve the Sophoclean tragedy by avoiding some inconsistencies and bringing the plot to perfection, Péladan is not afraid of breaking these neoclassical rules by introducing a hybrid being like the Sphinx on stage. Finally, if there is no unity of place, Péladan's play evolves, however, within a reasonably short time, from the murder of Laius to his funeral and the victory over the Sphinx.

But how could Péladan justify ending the play with the union of Oedipus and Jocasta? He himself, in his Origine et Esthétique de la Tragédie (1905), admits that this new approach to Greek tragedy is not entirely his own original idea:

La culture occidentale commence à découvrir l'hellénisme. Il n'y a pas longtemps, elle tenait compte de Sénèque le tragique et nommait Voltaire après Corneille et Racine. [...] Entre le chant du bouc du VII siècle avant Jésus-Christ et Cinna par ex., il y a vraiment un abîme; et le premier qui l'ait mesuré est ce fameux Nietzsche qui mérite, autant par sa puissance célébrale que par son étrangeté, de partager avec Paracelse l'épithète de docteur illuminć. L' Origine de la tragédie, que nous pouvons lire en français, grâce à $M$. Albert, projette une clarté sur la naissance du drame [...] (Ch. II; pp. 29-30).

As he admits, Péladan had already read Nietzsche's The Birth of Tragedy in $M$. Albert's translation, and his judgement on Nietzsche shows the latter's importance in changing the attitudes toward Greek tragedy and Oedipus the King in late 19th- and early 20th-century. To comprehend the extent of Nietzsche's influence on Péladan, we shall discuss which Nietzschean ideas regarding Greek tragedy and Oedipus the King have been illustrated in Péladan's CEdipe et le Sphinx.

\section{(b) Friedrich Nietzsche and The Birth of Tragedy}

In The Birth of Tragedy, Nietzsche founded his approach to Greek art on the distinction of Dionysian and Apollonian elements and their constant struggle for domination. For him, whereas music, wild enthusiasm and delirium represent the Dionysian world, 
sculpture and the aesthetic pleasure, dream and illusion belong to the world of Apollo. For many centuries, claims Nietzsche, only the Olympian, serene perfection of form had been admired; yet, this seeming Apollonian "naïve" art is very rare and always has to be founded in the overcoming of terrible suffering. It is because of this terrible suffering that the Greeks needed the Olympian gods to hide the dreadful foundation of all reality. Thus, he concludes that in Greek art the Dionysian and Apollonian forces, after a continual struggle for mutual destruction, finally reached their reconciliation in Attic tragedy.

Moreover, the starting point in Nietzsche's theory on tragedy and its evolution is his basic assumption that the tragic chorus of satyrs, the servants of Dionysus, is the origin of tragedy. For him, chorus has primarily a religious function in which myth (mythos) ${ }^{22}$ and the cult of Dionysus were closely associated. He also believes that even in its most perfect form, tragedy always represents the sufferings of Dionysus himself under the mask of a great hero. His ideas on the interrelation of Dionysian and Apollonian forces in tragedy and their effect on the audience are highly ritualistic and too complex to be analyzed here. What is interesting, however, is that Nietzsche's "discovery" of the Dionysian quality of tragedy is largely responsible for the rejection of neoclassical views in approaches to, and re-interpretations of, Greek myths and tragedies in our century.

For our discussion, another important aspect of The Birth of Tragedy is Nietzsche's interpretation of Sophocles' Oedipus the King. He asserts that there is an inherent conflict within the characters themselves; he sees a fundamental difference between the characters as they are represented by the tragedians, with an Apollonian mask and the deeper, most frightful reality of the myth (mythos) itself behind them. Then Nietzsche challenges the

22. We can see how Nietzsche re-interprets the Aristotelian notion of mythos as «legend", "story" or "myth", and relates it to the chorus and the tragic hero. For a brief discussion of the same matter, see section 1 of this article. 
contemporary literary status quo by maintaining that the myths themselves rather than the literary works should be studied and imitated. For him, the image of Oedipus that Sophocles delineates for us is one side of his tragedy only, the moral and Apollonian aspect. It should never be forgotten, however, Nietzsche maintains, that this superior serenity lying over the whole work is only to hide the monstrous, preceding events that have led to this situation:

If this explanation has done the poet justice, it may yet be asked whether it has exhausted the implications of the myth; and now we see that the poet's entire conception was nothing more or less than the luminous afterimage which kind nature provides our eyes after a look into the abyss. Oedipus, his father's murderer, his mother's lover, solver of the Sphinx's riddle! What is the meaning of this triple fate? (Nietzsche, 1956, p. 61)

This passage contains two important points; the first is a consideration of the events before the opening scene of the Sophoclean tragedy in an effort to explain the characters and the process itself that led to the situation of the tragedy itself. This new emphasis is exactly the tendency reflected in Péladan's CEdipe et le Sphinx and other 20th-century re-interpretations of the Oedipus myth. The second point is Nietzsche's particular attitude towards Oedipus. He considers the Sphinx as the crucial point of the myth, making no mention of the Delphic oracle. For him, the monstrosities of parricide and incest could only be committed by a man of unnatural wisdom who was also able to solve the riddle of nature and to destroy a hybrid being like the Sphinx. The striking aspect of this approach to Oedipus, however, is the description of the victory over the Sphinx, a decisive moment in Oedipus' life, that cannot be found in Greek literature at all! Undoubtedly, Nietzsche's preoccupation with the religious aspect of myth, his effort to unravel the deeper level of Greek tragedy, and his focus on the Sphinx rather on the Delphic oracle have had a significant impact on most contemporary writers who have tried to re-write the Oedipus story. One thing has become evident since the turn of this century: the Sphinx has come to be part of most contemporary versions of Oedipus (primarily French 
and German) of which the first and best example is Péladan's CEdipe et le Sphinx.

\subsection{England}

During the same period, the situation in England was quite different. Compared to France, Great Britain surprises us with its proliferation of prose and verse translations of Oedipus and the absence of any radical re-interpretation of the story of Oedipus. One possible explanation of that lack of re-interpretation might be an interrelation of two dynamics; the strong influence of philology and the lack of a strong neoclassical tradition seem to have helped the translations of Greek tragedy and Oedipus the King to be more in the centre than in the periphery of the English market. This abundance of translations, which were made primarily by classical scholars, can be attributed to many different factors. The ongoing English public interest in Greece itself, ${ }^{23}$ the very significant archaeological finds, the two conflicting German theories on the structure of the Greek stage, Nietzsche's theories on Greek tragedy and the emergence of philology as a science fuelled the interest of the English public in Greek tragedy as literature and created a demand for more translations.

Among all these translations of Oedipus the King two stood out and became landmarks in the English-speaking world:

23. That interest had been fostered by: (1) the British educational system which had laid stress upon the classics; (2) the dedication of some British scholars of the period, such as C.J. Bloomfield, J.H. Monk, P.P. Dobree, and P. Elmsley, to carry on the work of Porson and edit Greek texts rather than Latin; (3) the removal of the marbles from the Acropolis by Lord Elgin and their arrival in England around 1801-1812; (4) the outbreak of the Greek War of Independence (1821-1829) and its support primarily from Romantics like Lord Byron. For the different factors which influenced the opening of the English market to the translations of Greek literature see Finley M.K. Foster, 1966, pp xiii-xxix. 
those of Sir R.C. Jebb and of Gilbert Murray. The former translated the Sophoclean tragedy as The Oedipus Tyrannus in English prose in 1883, while the latter felt the need to render this tragedy once again as Oedipus, King of Thebes, but much later, in 1911. These translators were both philologists who, of course, did not function in a vacuum. Having come out of the Porsonian tradition of textual scholarship, ${ }^{24}$ Jebb and Murray were only two among other classical scholars who translated Oedipus the King either into English prose with thorough annotations, footnotes and appendices, ${ }^{25}$ or into English verse. ${ }^{26}$ In the following two sections, we shall venture to show how Jebb and Murray's translations of Oedipus are different from other English translations of the same tragedy, and why they became so important for both the British and North American TSs.

24. Maintaining Bentley's textual scholarship, Richard Porson (1759-1808) did textual work of high quality, mostly on the Attic drama. For a discussion of his life and contribution to classical scholarship, see M.L. Clarke, 1973.

25. To name a few: (1) T.W.C. Edwards, Oedipus Tyrannus (1823); (2) Benjamin Hall Kennedy, The Oedipus Tyrannus of Sophocles (1882); and (3) Edward P. Coleridge, Oedipus the King. The Tragedies of Sophocles [Bohn's Classical Library] (1893).

26. Some of the other poetic translations were those by: (1) E.H. Plumptre, Oedipus the King. The Tragedies of Sophocles (1877); (2) William Wells Newell, The Oedipus Tyrannus of Sophocles (1881); (3) Robert Whitelaw, Oedipus the King. Sophocles (1883); (4) E.D.A. Morshead, Oedipus the King (1885); (5) John Swinnerton Phillimore, Oedipus Tyrannus. Sophocles (1902); (6) Lewis Campbell, King Oedipus. Sophocles (1874/1896/1906); (7) Arthur S. Way, Oedipus the King. Sophocles in English Verse (1909); (8) Sir George Young, Oedipus Tyrannus. The Dramas of Sophocles (1888/1906); and (9) Francis Storr, Oedipus the King. Sophocles (1912). 


\subsubsection{Jebb's The Oedipus Tyrannus: A Philological Discourse}

As noted earlier, Jebb had his first edition of The Oedipus Tyrannus published in 1883. It was, however, the 1893 edition $^{27}$ and its subsequent reprints that became really popular on both sides of the Atlantic. The significance of that edition lies in that it is a painstaking, meticulous philological translation in which the order of the Greek clauses and the smallest particles are carefully reproduced. The translator's introduction, translation, extensive footnotes, commentaries and appendices reveal the spirit of his period for us. Many factors such as important archaeological excavations, the development of philology as a science, and modes of literary criticism, had combined to encourage Jebb, among other classical scholars, to approach a theatre text such as Oedipus the King as a philological document. The result was a scholarly approach demanding a strict scientific analysis and presentation of his material. It was designed primarily for bilingual readers, i.e. for English-speaking scholars and students of Classics with sufficient knowledge of Greek to read the original, compare it with the juxtaposed translation in prose, and benefit from the critical notes and commentaries. Then the primary function of that translation was to be faithful to and elucidate the source text (ST).

Although Jebb's The Oedipus Tyrannus is a literal and scholarly translation, it occupies a special position in the two already differentiated but interacting British and North American TSs for two reasons. First, and in contrast with the current assumption that a literal translation cannot be performed, the dialogues of Jebb's prose translation were used for performances in Cambridge in 1887 and in 1912 (Jebb, 1887a and 1912). Second, if contextualized within the official British disposition towards this Sophoclean tragedy, ${ }^{28}$ these performances of Jebb's The Oedipus Tyrannus in Cambridge are of a great importance for the British theatre, because they make clear that Oedipus was only

27. Hereafter any quotations are from this edition.

28. About the banishment of Oedipus the King, see section 3.2.2. 
possible to perform on the British stage when it was performed in any other city than London, and when the performances were under the auspices and authority of traditional departments of Classics like that at the University of Cambridge.

Another extraordinary aspect of the importance of this translation is that it dominated the British and North American reading markets for a century through World Drama anthologies. As early as 1916 Brander Matthews chose Jebb's text for his collection The Chief European Dramatists making, however, two important editorial changes (Jebb, 1916, pp. 31-53). He first changed the title from The Oedipus Tyrannus into Oedipus the King and then omitted the original Greek text, introduction and commentaries, while keeping Jebb's translation as it appeared in the 1893 edition.

Much later, the same translation was also chosen as the "standard version" of Oedipus the King in other anthologies of Greek literature, such as: The Complete Greek Drama (Jebb, 1938, pp. 363-418), Greek Literature in Translation (Jebb, 1944, pp. 241-272), Seven Famous Greek Plays (Jebb, 1950, pp. 117-182) and Great Books of the Western World (Jebb, 1952, pp. 99-113). Some of the reasons why all these editors chose Jebb's rendering of Oedipus are explicitly stated in the introductions or prefaces to their anthologies. They thought that Jebb's text was "the best available translation" (Jebb, 1938, p. vii), providing the "essential correspondence to the Greek original considered as a whole." They also praised its "close fidelity [...] to the original in specific detail" (Jebb, 1938, p. vii). The editors of these anthologies did what Brander Matthews had done before; they all changed the title from The Oedipus Tyrannus to Oedipus the King, omitted all the philological comments and retained Jebb's translation of Oedipus only. The main reason for these editorial changes seems to have been that these anthologies were aiming at a wider readership which, although it did not have any background in Greek Studies, was eager to learn more about Greek tragedy and Sophocles' Oedipus the King through a "faithful" translation. Therefore, we can claim that the use of Jebb's The Oedipus Tyrannus in World Drama anthologies can be one of the strongest 
advocates of the predominance of philological discourse, and also signifies how subtly and intrinsically this discourse has been interwoven in the perception and reception of Sophocles' Oedipus by the English-speaking world for almost a century.

An additional function of this translation, which is the last mentioned, if not totally ignored, by classical studies but which is of great importance for translation studies, is that it has become the primary source for new versions of Oedipus the King for stage performance. Two examples of this intralingual intertextuality are W.B. Yeats's Sophocles' King Oedipus (1928) and Stephen Spender's King Oedipus (1985). Although the whole question of intralingual intertextuality in these versions goes beyond this study, it is enough to say in the present context that textual evidence shows that both Yeats and Spender employed Jebb's translation as their primary source to make their versions. In these two cases of intertextuality, the importance and the impact of philology for and upon later English versions of Sophocle's Oedipus the King is more discernible than ever before.

3.2.2. Gilbert Murray's Oedipus, King of Thebes and Max Reinhardt's Production of Oedipus Rex: Politics, Philology and Philosophy in a Translation and its Theatrical Production

Although Gilbert Murray's translation Oedipus, King of Thebes was only one among many poetic translations of Oedipus, ${ }^{29}$ it occupies a special position in the British TS because of its use in the Reinhardt production at Covent Garden on 15 January 1912. To understand the significance of this translation by Murray for Great Britain, we should consider the existence of two different but conflicting dynamics within the British TS at the turn of the century, namely, the emergence of the Greek theatre movement and the banishment of Oedipus the King from the British stage. On the one hand, the Greek theatre movement in England began in

29. For more information about the other verse translations of Oedipus, see footnote 26 of this paper. 
the $1880 \mathrm{~s}$ with the rediscovery of Greek theatre architecture ${ }^{30}$ and was further developed by the early work of theatre people and classical scholars such as Sybil Thorndike, Granville Barker and Gilbert Murray. From 1900 to 1914, that group of actors, producers and classical scholars were concerned primarily with a revival of Greek drama based on new archaeological theories on classical theatre and tried to have proscenium stages converted to resemble Greek theatres.

On the other hand, Oedipus the King was for many years regarded as impossible for the English stage. The frustration of many actors, dramatists and theatre people can be seen in Sir Herbert Tree's case and in Henry Arthur Jones' protest. The former, desiring to produce this Sophoclean tragedy at His Majesty's Theatre, was prevented by the Censor on the basis that "the licence had been refused before, and that it was no use submitting the play again" (Fowell and Palmer, 1969, p. 275). The latter, attacking this official shortsightedness, states sardonically: "Now, of course, if any considerable body of Englishmen are arranging to marry their mothers, whether by accident or design, it must be stopped at once. But it is not a frequent occurrence in any class of English society. Throughout the course of my life I have not met more than six men who were anxious to do it" (Fowell and Palmer, 1969, p. 275, note 1). Such a statement clearly indicates that the main reason for the refusal of any production of Oedipus the King must have been the incestuous relationship of Oedipus and Jocasta.

In spite of that official resistance in staging Oedipus the King, censorship was lifted in late 1911 and early 1912. As Fowel and Palmer report, "in time the Censor slowly followed public opinion, and the Oedipus was performed at Covent Garden in 1912 for twenty-six performances, with the most unstinted public approval" $(1969$, p. 275). Of course, these performances were none other than Reinhardt's production of Oedipus Rex in Murray's

30. Peter Arnott notes that the German archaeological discoveries of Höpken and Dörpfeld in the 1880s and 1890s altered the concept of classical Greek theatre (Peter Arnott, 1962, p. 3). 
translation. That production opened in London on January 15, 1912 with Martin Harvey as Oedipus, Lillah McCarthy as Jocasta and Franklin Dyall as the Messenger (Smith and Toynbee, 1960, p. 161).

Both the translation of Oedipus by Murray and Reinhardt's production raised much controversy among contemporary critics, philologists and playwrights. ${ }^{31}$ Classical scholars like J.T. Sheppard, accused Reinhardt's production of being a "lavish, barbaric and turbulent" one, and Murray's translation as "highly charged with metaphor, and very often vague" (J.T. Sheppard, 1920, pp. ix and $x$ respectively). Nevertheless, playwrights, such as W.B. Yeats, praised Reinhardt's production as "a most wonderful production" (Clark and McGuire, 1989, p. 33).

The translation by Murray and the theatrical performances produced by Reinhardt are also very important for the present study because they indicate how a translation and a theatrical production became topoi of philological and philosophical discourses. Second, although Murray was a classical scholar, he dared not only to translate Oedipus in rhyming verse but also to take many liberties to make this tragedy accessible to a wide English reading public; and indeed, the 1911 edition of his Oedipus, King of Thebes succeeded in doing that. When the same translation was used in the Reinhardt production, it made Sophocles' Oedipus accessible to a wide British theatrical audience too. In his reply to The Times (January 23, 1912) concerning Reinhardt's production of Oedipus Rex in his translation, Murray claims:

Vast audiences come to hear the Oedipus - audiences at any rate far greater than $\mathrm{Mr}$. Granville Barker and I have ever gathered, except perhaps once; they sit enthralled for two hours

31. For the impact of Max Reinhardt's production on his contemporary British theatrical audience, see Clark and McGuire, 1989, pp. 32-33. 
of sheer tragedy, and I do not think many of them will forget the experience. (Smith and Toynbee, 1960, p. 161)

In this statement, Murray admits boldly that Oedipus the King in his translation became accessible to a wide English theatrical audience only with Reinhardt's production.

Third, Max Reinhardt was the most famous, but also the most controversial, German producer of that time. Having already produced Hugo von Hofmannsthal's Konig Ödipus von Sophokles (1910) in Germany with great success, he ventured to produce Oedipus Rex in Murray's translation in London. ${ }^{32}$ His 1912 London production was the most important production for the Greek theatre movement, and changed radically the relation between performers and spectators in Britain.

Reinhardt based his productions of Oedipus Rex on German theories of Greek theatre design which had been developed from two conflicting archaeological presuppositions. Had there been, as Vitruvius claimed, a large raised stage separating actors from chorus and spectators, or had there simply been a long step against the scene wall, with all performers using the orchestra space, distinguished only by costume and mask (Arnott, 1962, pp. 3-4)? That archaeological controversy had affected changes in German theatre, and Richard Wagner was the first to apply these conflicting theories by having his theatre designed based on the architecture of the Greek theatre (Symons, 1968, pp. 283-321). When Wagner's theatre at Bayreuth was completed, it soon became the model for the Greek theatre

32. J.L. Styan states that Reinhardt's Oedipus Rex opened in the Festhalle in Munich in 1910. It went to Vienna in October 1910, to Budapest with Hungarian players in October 1910, in the Zirkus Schumann, Berlin, on 7 November 1910, in Covent Garden, London, with English players on 15 January 1912, to St. Petersburg, Moscow, Riga, Warsaw, Kiev, Odessa, and Stockholm, in winter 1912 (Styan, 1982, pp. 78-80). For a discussion of the world success of Reinhardt productions of Oedipus Rex, see also Sayler, 1924. 
movement in England. But it was not until Reinhardt's production of Oedipus Rex at Covent Garden in 1912 that large audiences in London could see that type of stage performance.

Reinhardt's production of Oedipus Rex in London was highly influential or so controversial, depending on the critic's perspective, because it was the first time that the British theatre audience saw controversial archaelogical, philological and philosophical theories regarding Greek theatre and tragedy applied to specific productions. But in his staging of Oedipus Rex Reinhardt did something more: he altered the relation between performers and spectators in ways which were revolutionary for that time.

According to his contemporary British theatrical critics, Reinhardt had an extraordinary impact on the perception of Greek tragedy in general and Oedipus the King in particular by the British audience for various reasons. First, he let "The actors [...] really move among the audience, there playing out their little drama in the midst of their fellow-men, just as the great drama is played every day of our life on earth" (Carter, 1964, p. 210); and he did that by having the proscenium stage and physical structure of the orchestal pit modified. Second, with this drastic modification of the interior structure of Covent Garden, Reinhardt gave the spectators the impression that they were participating in the action unfolding before them (Carter, 1964, p. 218). Third, to enhance this impression, Reinhardt did something more. Having the acting area extended towards the audience, he drew the audience towards the actors on stage because:

A space was cleared in front of the stage by removing rows of stalls, for the chorus and crowd to act in and mix with the spectators. The front row of the stalls was, in fact, in touch with the outer fringe of the crowd, while all the players made their entrances and exits through the audience at various points of the arena. (Carter, 1964, p. 218)

Nonetheless, the most powerful connection beween the spectators and performers in these performances was not simply the modification of the physical structure of Covent Garden; it 
was the large chorus, whose impact upon its contemporary British audience is described as follows:

Perhaps the most artistic effect was that attained by the crowd and Oedipus. Oedipus stood on the rostrum calm and self-possessed. Beneath him surged the infuriated mob, with outstretched arms, swelling up to him like a sea of angry emotions, and returning thence to the Leader of the Chorus in response to his call. There on one side Oedipus stood like an intellectual pinnacle islanded in the billowing ocean of human beings; and there on the other side the Leader stood like the Spirit of the Infinite swayed to and fro by elemental passions. (Carter, 1964, pp. 218-219)

We cannot help but notice the resemblance between Reinhardt's production of Oedipus Rex and Nietzsche's "ideal spectator" of an ancient Greek performance. In The Birth of Tragedy, Nietzsche sees the dramatic form of Greek tragedy primarily originating in the Dionysian chorus:

The chorus is the "ideal spectator" inasmuch as it is the only seer - seer of the visionary world of the proscenium. An audience of spectators, such as we know it, was unknown to the Greeks. Given the terraced structure of the Greek theater, rising in concentric arcs, each spectator could quite literally survey the entire cultural world about him and imagine himself, in the fullness of seeing, as a chorist. Thus we are enabled to view the chorus of primitive prototragedy as the projected image of Dionysiac man. The clearest illustration of this phenomenon is the experience of the actor, who, if he is truly gifted, has before his eyes the vivid image of the role he is to play. The satyr chorus is, above all, a vision of the Dionysiac multitude, just as the world of the stage is a vision of that satyr chorus - a vision so powerful that it blurs the actors' sense of "reality" of cultured spectators ranged row on row about him. The structure of the Greek theater reminds us of a lonely mountain valley: the architecture of the stage resembles a luminous cloud configuration which the Bacchae behold as they swarm down from the mountaintops; a 
marvelous frame in the center of which Dionysos manifests himself to them. (Nietzsche, 1956, p. 54) ${ }^{33}$

The last but least known aspect of that production is the interaction between Murray and Martin Harvey, the actor who played the role of Oedipus. After Reinhardt's production of Oedipus Rex had been criticised as sensational and non-Greek and after Murray had sent a long letter to The Times as a response to those criticisms, Murray also wrote a letter to Martin Harvey suggesting to him the following:

I think your first entrance, blinded, should be less realistic, more symbolic; it is lyrical in the Greek, that means beauty and music and remoteness from realism [...] Drop all the use of the mere physical horror $[\ldots]$ or almost all. $\mid . .$.$] The greatness of the$ man triumphs over all the sin and misery and suffering. $[. .$. But I want the impression to come earlier. I should like to feel, right from your first entrance blinded, "here is a man who has been through all suffering and come out at the other end; who has done judgement on himself to the uttermost and now stands above all common men." I want to feel the man's greatness and the mystery of him. [...] Now do I take you with me in all this? (Smith and Toynbee, 1960, p. 162; his emphasis)

Harvey's astonishingly co-operative attitude towards this constructive criticism is shown in his letter to Murray:

I like all you say about the treatment of the playing - say as much more as you feel, I shall greatly appreciate it - my own feeling was throughout for more retinence in the movement in the rush of the rehearsals I got rather carried off my feet when you see it next you will find it improved I think - and along the lines you indicate. (Smith and Toynbee, 1960, p. 162)

A careful reading of the exchange of these letters indicates the interplay of three different dynamics. First, there was a close relationship between the translator and the protagonist of the

33. The significance of the chorus in Nietzsche's The Birth of Tragedy has been discussed in section 3.1.2. (b). 
production which, in theatrical terms, can only be described in the most positive terms, because it signifies an active participation of the translator in the process of staging his own translation. Second, the above-mentioned excerpt from Murray's letter to Harvey shows that the former believed and interpreted Oedipus the King as "less realistic, more symbolic." When contextualized, his letter susggests that Murray as a classical scholar, poet, translator and producer participated in the movement of the Non-Naturalist drama in England. His emphasis on the "remoteness from realism" in Oedipus can be understood as a revolt against the grain of the Naturalist theatre that was advocated by Ibsen and his followers in England. Finally, when Murray draws Harvey's attention to "the greatness of man [ who] triumphs over all the sin and misery and suffering" and to "a man who [...] now stands above all common men" suggesting to him "to feel the man's greatness and the mystery of him," we can identify the radical shift of emphasis from the Aristotelian notions of plot (mythos) and action to the Nietzschean interpretation of myth (mythos) and his concept of the overman (Übermensch) $)^{34}$ whose main proponent is Oedipus, the man who "stands above all common men."

To understand the strong parallelism between Murray's statements about the character of Oedipus and Nietzsche's overman, we should recall how Nietzsche perceives the overman. He envisions him as the human being (Mensch) who has organized the chaos of his passions, given style to his character and become creative. Aware of life's terrors, the overman affirms life without resentment. With only a few exceptions, ${ }^{35}$ Nietzsche uses overman in singular and usually as a worldly antithesis to God. According to Nietzsche, man (Mensch) should not conceive

34. In this article I follow Walter Kaufmann who uses overman for Übermensch instead of the term superman, coined by B. Shaw (Kaufmann, 1968; pp. 307-333).

35. The only passage in which the notion of overman is used in plural is "Von den Dichten» (Nietzsche, 1955, pp. 382-385), which is by itself an ironic, self-critical passage. 
perfection as given or a fact (gegeben) but as a task (aufgegeben) that few approach. ${ }^{36}$ There is no meaning in life except that which man gives his life, and the aims of most men have no surpassing dignity. To raise oneself above the senseless flux, one must cease to be merely human, all-to-human (Menschliches, Allzumenschliches). One must be hard on oneself; one must become a creator instead of remaining a mere creature. In aphorism 910 of The Will to Power (Der Wille zur Macht) Nietzsche epitomizes his concept of the overman when he wishes to those he wishes well:

suffering, being forsaken $[\ldots]$ profound self-contempt, the torture of mistrust of oneself, the misery of him who is overcome [...] (Nietzsche, 1952, p. 613; translation mine)

The striking resemblance between Nietzsche's statement about the overman and Murray's statements about the character of Oedipus in his letter to Martin Harvey, leaves no doubts about the influence of Nietzsche's work upon Murray and his interpretation of this tragedy. We can certainly uphold that Murray, when translating Sophocles' Oedipus the King, had not only read but also internalized some of the most important books by Nietzsche, mainly The Birth of Tragedy and The Will to

36. This approach is directly related to Nietzsche's notion of the will to power which was first conceived as the will to overcome oneself, then developed as the will to overcome one's neighbour and, finally, was fully exposed in his book The Will to Power. For the will to overcome oneself, see primarily Nietzsche, 1955, pp. 322-324 and 369-372 respectively. For the will to overcome one's neighbour, see Nietzsche's aphorisms: 63 (Book 1), 118 and 146 (Book 2) in Nietzsche, 1954, pp. 1053, 1093-1096 and $1115-1116$ respectively. 
Power. ${ }^{37}$ Since 1912 Murray's translation was used both for productions and in World Drama anthologies. ${ }^{38}$

\section{Conclusion}

The above discussion leads us to the conclusion that philosophical, political and philological discourses can indeed play a vital role not only in the making of translations, imitations, reinterpretations and theatrical performances of a "canonical" tragedy like Sophocles' Oedipus the King but also in the reception of this tragedy by various target systems at particular times. Nevertheless, the historical inquiry of this article points to the fact that the influence of these discourses upon French and British translations, versions and performances of Oedipus the King can vary and result in different perception and reception of this play by these TSs. It seems that, whereas French playwrights, creative writers, translators and performers were always ready to experiment with and, eventually, re-interpret the Oedipus character and myth, the British were always more conservative with their own choices and preferred to follow the story-line of Sophocles' Oedipus.

This striking difference in perception and reception of Oedipus the King by the French and British TSs during particular periods, such as the late 17 th and early 18 th century, and late 19th and early 20th century, can be attributed to the systems themselves. On the one hand, it is conspicuous that Sophocles' Oedipus the King was always received by the French public primarily through the neoclassical versions of $C E$ dipe by Corneille and Voltaire, and radical re-interpretations of the Oedipus myth, such as Péladan's CEdipe et le Sphinx. As a result, Sophocles' Oedipus was always more in the periphery than in the centre of the French TS. On the other hand, in England the strong

37. The same observation but from a different angle has been expressed in M.S. Silk and J.P. Stern, 1981, Pp. 143-145.

38. For more information, see under «Murray» in the References of this paper. 
influence of philology brought Oedipus the King more in the centre than in the periphery of its market, and made this tragedy be considered as one of the most important classical tragedies to be read, taught and performed.

Finally, this study shows that the impact of the discourses of philosophy, politics and philology upon the reception of a Greek tragedy like Oedipus the King by the French and British TSs during particular periods can be a gold-field for transaltion, theatre and comparative studies, a field whose only a very small part has been explored in this essay.

\section{University of Alberta}

\section{References}

ABRAHAM, Claude (1972). Pierre Corneille. New York, Twayne.

ARNOTT, Peter (1962). Greek Scenic Conventions in the Fifth Century B.C. Oxford, Clarendon Press.

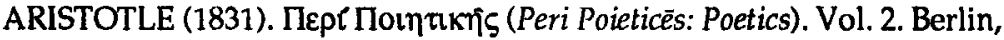
Georigium Reimerum. pp. 1447-1462. 5 vols.

BOUHÉLIER, Saint-Georges de (1919). CEdipe, Roi de Thebes, pièce en trois parties et seize tableaux, accompagnée d'une musique de scène, tirée par M.H.-M. Jacquet des œuvres de J.-S. Bach. Paris, E. Fasquelle.

CAMPBELL, Lewis (1874). King Oedipus and Philoctetes translated into English Verse. Edinburgh, (no publisher).

(1896). King Oedipus. Sophocles. The Seven Plays in English Verse. New ed. rev. London, J. Murray. pp. 103-159.

(1906). King Oedipus. Sophocles. The Seven Plays in English Verse. New ed. rev. London \& New York, H. Frowde -- Oxford University Press. pp. 83-128. 
(1906a). King Oedipus. Sophocles. The Seven Plays in English Verse. New ed. rev. London, New York \& Toronto, H. Frowde - Oxford University Press. pp. 83-128.

(1906b). King Oedipus. Sophocles. Oxford, Oxford University Press \& London, Humphrey Milford. pp. 83-128.

CARTER, Huntly (1964). The Theatre of Max Reinhardt. Rpt. New York, Benjamin Blom.

CLARK, David R. and James B. McGuire (1989). W.B. Yeats. The Writing of Sophocles' King Oedipus. Philadelphia, The American Philosophical Society.

CLARKE, M.L. (1973). Richard Porson. 1 Biographical Essay. Rpt. Folcroft Library Editions.

COLERIDGE, Edward P. (1893). Oedipus the King. The Tragedies of Sophocles. [Bohn's Classical Library]. London \& New York, George Bell \& Sons. pp. 1-65.

CORNEILLE, Pierre (1987). CEdipe. Tragédie. CEuvres completes. Éd. Georges Couton. Tome 3. Paris, Gallimard. pp. 13-93. 3 tomes.

DRYDEN, John (1812). CEdipus. The Works of John Dryden. Ed. Sir Walter Scott. Vol. VI. Edinburgh, Archibald Constable \& London, Hurst, Robinson. pp. 115-225. 18 vols.

(1956). "Preface." Ovid's Epistles. The Works of John Dryden. Vol. 1. Berkeley \& Los Angeles, University of California Press. pp. 109-119. 20 vols.

(1970). John Dryden. Selected Criticism. Eds. James Kinsley and George Parfitt. Oxford, Clarendon Press.

(1971). Heads of an Answer to Rymer. The Works of John Dryden.Vol. XVII. Berkeley, Los Angeles \& London, University of California Press. pp. 185-193. 20 vols.

(1984). Oedipus. The Works of John Dryden. Vol. XIII. Berkeley, Los Angeles \& London, University of California Press. pp. 113-215. 20 vols. 
EDWARDS, T.W.C. (1823). Oedipus Tyrannus. London, Simpkin, Marshell.

FOWEL, Frank and Frank Palmer (1969). Censorship in England. Rpt. New York \& London, Benjamin Blom.

FOSTER, Finley Melville Kendall (1966). English Translations from the Greek. A Bibliographical Survey. New York, AMS Press.

HOFMANNSTHAL, Hugo von (1906). Ödipus und die Sphinx. Berlin, S. Fischer Verlag.

(1910). Konig Ödipus von Sophokles. Berlin, S. Fischer Verlag.

JEBB, Sir R.C. (1883). The Oedipus Tyrannus. Sophocles. The Plays and Fragments. Vol. 1. Cambridge, Cambridge University Press. 6 vols.

(1887). The Oedipus Tyrannus. Sophocles. The Plays and

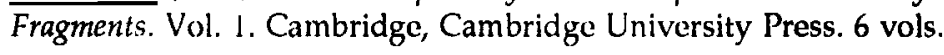

(1887a). The Oedipus Tyrannus of Sopholces, as arranged for performance at Cambridge, 1887. (I) The text in Greek and English. (II) The incidental music written by $C$. Villiers Stanford. Cambridge: Macmillan, 1887. - The Greek text and the English prose translation [...] from Professor Jebb's second eddition of the play [...] The translation of the choruses into English verse $|\ldots|$ by A.W. Verral. Cambridge, Macmillan \& Bowes.

(1893). The Oedipus Tyrannus. Sophocles. The Plays and Fragments. with critical notes, commentary and translation in prose. Vol. 1. Cambridge, Cambridge University Press. 6 vols.

(1904). "Oedipus the King." The Tragedies of Sophocles. Cambridge, Cambridge University Press. pp. 1-58.

(1912). Oedipus Tyrannus of Sophocles as performed at Cambridge, November 22-26, 1887, November 26-30, 1912. With a translation in prose by the late Sir R.C. Jebb [...] and a translation of the songs in verse $[\ldots \mid$ by the late A.W. Verrall. Cambridge: Bowes \& Bowes.

(1916). "Oedipus the King." The Chief European Dramatists. Ed. Brander Matthews. Boston, New York, Chicago, Houghton Mifflin \& Cambridge, Mass., The Riverside Press. pp. 31-53. 
(1938). "Oedipus the King." The Complete Greek Drama. Eds. W.J. Oates and Eugene $O^{\prime}$ Neil. Vol. 1. New York, Random House. pp. 363-418. 2 vols.

(1944). "Oedipus the King." Greek Literature in Translation. Eds. W.J. Oates and Sh.T. Murphy. New York, Longmans. pp. 243-272.

(1950). "Oedipus the King." Seven Famous Greek Plays. Eds.

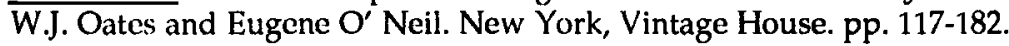

(1952). "Oedipus the King." Great Books of the Western World. Ed. Robert M. Hutchins. Vol. 5. Chicago, London \& Toronto, Encyclopedia Britannica. pp. 99-113.

JOANNIDèS, A. (1901). La Comédic-Franģaise de 1680 à 1900. Paris, Librairie Plon.

KAUFMANN, Walter (1968). Nietzsche. Philosopher, Psychologist, Antichrist. Princeton, N.J., Princeton University Press.

KENNEDY, Benjamin Hall (1882). The Oedipus Tyrannus of Sophocles. Cambridge, Cambridge University Press.

KINDERMANN, Heinz (1970). Theatergeschichte Europas. Bd VIII. Salzburg, Otto Müller Verlag.

LACROIX, Jules (1858). CEdipe Roi, tragédie de Sophocle traduit littéralement en vers français par Jules LaCroix. Paris, Lévy.

(1859). CEdipe Roi, tragédie de Sophocle traduit littéralement en vers français par Jules LaCroix. Paris, Michel Lévy frères.

(1861). CEdipe Roi, tragédie de Sophocle traduit littéralement en vers français par Jules LaCroix. 2ème éd. Paris, M. Lévy.

(1874). CEdipe roi, tragédie en cinq actes. Jules LaCroix. CEuvres. Théâtre. Tome I. Paris, Lévy.

(1881). CEdipe Roi, tragédie de Sophocle traduit littéralement en vers français par Jules LaCroix. Nouv. éd. Paris, C. Lévy. 
(1883). CEdipe Roi, tragédie de Sophocle traduit littéralement en vers français par Jules LaCroix. Nouv. éd. conforme à la représentation. Paris, Calmann Lévy.

(1888). CEdipe Roi, tragédie de Sophocle traduit littéralement en vers français par Jules LaCroix. Paris, Calmann Lévy.

(1890). CEdipe Roi, tragédic de Sophocle traduit littéralement en vers français par Jules LaCroix avec une suite de composition dessinée par J. Mazorolle, précédée d'une étude par Gustave Laroumet. Nouv. éd. Paris, Société de propagation des livres d'art.

(1892). CEdipe Roi, tragédic de Sophocle traduit littéralement en vers français par Jules LaCroix. Nouv. éd. conforme à la représentation. Paris, Calmann Lévy.

(1894). CEdipus the King. Tragedy by Sophocles in five acts. Trans. literally into French verse by Jules LaCroix. And into English verse by Frederic Lyster. [...] New York, F. Rullman.

(1899). CEdipe Roi, tragédie de Sophocle traduit littéralement en vers français par Jules LaCroix. Paris, Calmann Lévy.

(1901). CEdipe Roi, tragédie de Sophocle traduit littéralement en vers français par Jules LaCroix. Nouv. éd. conforme à la représentation. Paris, Calmann Lévy.

MORSHEAD, E.D.A. (1885). Oedipus the King. London: Macmillan.

MURRAY, Gilbert (1911). Sophocles. Oedipus, King of Thebes; trans. into English rhyming verse, with explanatory notes. London, George Allen \& Unwin.

(1935). Oedipus, King of Thebes. Ten Greek Plays. Eds. Lane Cooper and H.B. Densmore. New York, Oxford University Press. pp. 1-49.

(1940). Oedipus, King of Thebes. Milestones of the Drama. Ed. Helen Louise Cohen. New York, Harcourt, Brace \& World. pp. 24-74.

(1960). Oedipus, King of Thebes. Fifteen Greek Plays. Ed. Lane Cooper. New York, Oxford University Press. pp. 161-210. 
NEWELL, William Wells (1881). The Oedipus Tyrannus of Sophocles. Cambridge, Charles W. Sever (University Bookstore).

NIETZSCHE, F. (1952). Friedrich Nietzsche. Der Wille zur Macht. Rpt. Stuttgart: Alfred Kröner.

(1954). Die Geburt der Tragödie. Friedrich Nietzsche. Ed. Karl Schlechta. Vol. 1. München: Carl Hanser. pp. 21-134. 3 vols.

(1954a). Morgenröte. Friedrich Nietzsche. Ed. Karl Schlechta. Vol. 1. München, Carl Hanser. pp. 1009 -1279. 3 vols.

(1955). Also Sprach Zaratustra. Friedrich Nietzsche. Ed. Karl

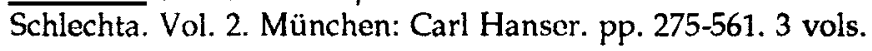

(1956). "The Birth of Tragedy." The Birth of Tragedy and The

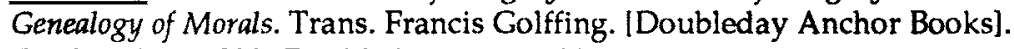
Garden City, N.Y., Doubleday. pp. 1-146.

PÉLADAN, Josephin (1897). CEdipe et le Sphinx. Tragédie selon Sophocle. Pour servir de prologue à L'CEdipe-roi. Théâtre de la Rose+Croix VI. Beauvais, Imprimerie professionnelle.

(1903). CEdipe et le Sphinx. Tragédie en trois actes. Texte conforme à la représentation du ler août 1903 au théatre antique d'Orange. Quatrième édition. Paris, Société du' Mercure de France.

(1905). Origine et Esthétique de la Tragédie. Paris: E. Sansot.

PHILLIMORE, John Swinnerton (1902). Oedipus Tyrannus. Sophocles. Vol. 2. New York, Longmans, Green \& London, George Allen. pp. 1-62.

PLUMPTRE, E.H. (1877). Oedipus the King. The Tragedies of Sophocles. London, Isbister. pp.1-55.

SAYLER, Oliver M., ed. (1924). Max Reinhardt and His Theatre. New York, Bretano's.

SENECA, Lucius Annaeus (1917). "Oedipus." Seneca's Tragedies. Trans. Frank Justus Miller. Vol. 1. [TheLoeb Classical Library]. London, William Heinemann \& New York, G.P. Putnam's Sons. pp. 425-523. 2 vols.

SHEPPARD, J.T. (1920). The Oedipus Tyrannus of Sophocles. Cambridge, Cambridge University Press. 
SILK, M.S. and J.P. Stern (1981). Nietzsche on Tragedy. Cambridge, Cambridge Uiversity Press.

SMITH, Jean and Arnold Toynbec, eds. (1960). Gilbert Murray. An Unfinished Autobiography. London, George Allen \& Unwin.

SOPHOCLES (1928). Oidinovs Tvpavvos (Oidipous Tyrannos: Oedipus Tyrannus). Sophoclis Fabulae. Ed. A.C. Pearson. Oxford, Clarendon Press. (no page numbers).

SPENDER, Stephen (1985). King Oedipus. The Oedipus Trilogy. London \& Boston, Faber \& Faber. pp. 27-90.

STORR, Francis (1912). Oedipus the King. Sophocles; with an English translation. [The Loeb Classical Library.

Greek Authors]. Vol. 1. London, W. Heinemann \& New York, The Macmillan. pp. 1-139. 2 vols.

(1929). Oedipus the King. Sophocles. Vol. 1. Rept. London: William Heinemann \& Cambridge, Mass., Harvard University Press. pp. 1-139. 2 vols.

STYAN, J.L. (1982). Max Reinhardt. Cambridge, Cambridge University Press.

SYMONS, Arthur (1968). "The Ideas of Richard Wagner." The Theory of the Modern Stage: An Introduction to Modern Theatre and Drama. Ed. Eric Bentley. Middlesex \& Baltimore, Penguin Books. pp. 283-321.

VOLTAIRE (1963). "Au Père Charles Porée. 7 janvier 1731." Correspondance de Voltaire. Éd. Théodore Besterman. Tome I. Paris, Gallimard. pp. 235-237. 11 tomes.

(1967). CEdipe. Tragédie en cinq actes avec des chours. CEuvres complètes de Voltaire. Éd. Louis Moland. Tome 2. Rpt. Nendeln/Licchtenstein, Kraus Reprint. pp. 5-111. 52 tomes.

WAY, Arthur S. (1909). Oedipus the King. Sophocles in English.Verse. London, Macmillan. pp. 5-79.

WHITELAW, Robert (1883). Oedipus the King. Sophocles. London, Rivingtons. pp. 1-64. 
YEATS, William Butler (1928). Sophocles' King Oedipu. A Version for the Modern Stage. London, Macmillan.

YOUNG, Sir George (1888). Oedipus Tyrannus. The Dramas of Sophocles, rendered in English verse, dramatic and lyric. Cambridge, Deighton, Bell \& London, G. Bell \& Sons. pp. 199-274.

(1910). Oedipus Tyrannus. The Dramas of Sophocles, rendered in

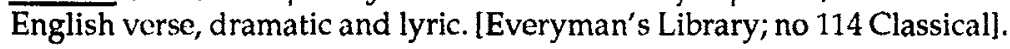
Ed. Ernest Rhys. London, J.M. Dent \& New York, E.P. Dutton. pp. 128-173.

ABSTRACT: Oedipus the King: A Greek Tragedy, Philosophy, Politics and Philology - This study tries to show that the abundance of translations, imitations and radical re-interpretations of a genre like tragedy is due to various social discourses of target societies. Taking as an example Sophocles' Oedipus the King, the acclaimed tragedy par excellence, this essay discusses how the discourses of philosophy, politics and philology influenced the reception of this classical Greek tragedy by the French and British target systems (TSs) during the late 17th and early 18 th century and the late 19 th and early 20 th century. The first section shows how, by offering Sophocles' Oedipus the King as a Greek model of tragedy, Aristotle's Poetics has formed the Western literary criticism and playwriting. The second section attempts to demonstrate why three imitations of Oedipus by Corneille (CEdipe), Dryden (Oedipus) and Voltaire (CEdipe) became more popular than any other contemporary "real" translation of the Sophoclean Oedipus. The third and final part holds that the observed revival of Oedipus the King in late 19th- and early 20thcentury France and England was due to the different degrees of influence of three conflicting but overlapping discourses: philosophy, philology and politics. It illustrates how these discourses resulted in different reception of the Greek play by the French and British TSs.

RÉSUMÉ: La tragédie grecque d'CEdipe roi: philosophie, politique et philologie - Cette étude tente de montrer que l'abondance des traductions, imitations ct réinterprétations radicales d'un genre comme la tragédie tient à divers discours sociaux des sociétés cibles. En prenant l'exemple d'CEdipe roi de Sophocle, tragédie célèbre s'il en est, cet essai traite de la façon dont les discours philosophiques, politiques et philologiques ont influé sur la réception de la tragédie grecque classique par les systèmes cibles français et britanniques à la fin du XVII siècle et au début du XVIII', ainsi qu'à la fin du XIX ${ }^{e}$ siècle et au début du $X X^{e}$. La première partie montre comment, en faisant de la pièce de Sophocle 
un modèle grec de tragédie, la Poétique d'Aristote a donné forme à la critique littéraire et à la dramaturgie occidentales. La deuxième partie essaie de montrer pourquoi trois imitations d'CEdipe par Corneille (CEdipe), Dryden (Oedipus) et Voltaire (CEdipe) ont connu plus de succès que n'importe quelle "réelle" traduction contemporaine de la pièce de Sophocle. La dernière partie présente l'hypothèse selon laquelle la renaissance d'CEdipe roi à la fin du XIX $\mathrm{X}^{\mathrm{e}}$ siècle et au début du $\mathrm{XX}^{\mathrm{e}}$ en France et en Angleterre est due à l'influence variable qu'exercent trois discours qui entrent en conflit mais aussi se chevauchent, ceux de la philosophie, de la philologie et de la politique. C'est une illustration de l'influence qu'exercent ces discours sur la réception de la pièce grecque dans les systèmes cibles français et britanniques. 